\title{
Screening of Bambara Groundnut (Vigna subterrenea Verdc. L.) Mutant Lines for Yellow Mosaic Virus Disease Resistance Using SSR Markers
}

\author{
Pranesh $^{1 *}$, R. Nandini ${ }^{1}$, Kailash Chandra ${ }^{3}$ and N. Nagaraju ${ }^{2}$ \\ ${ }^{1}$ Department of Genetics and Plant Breeding, College of Agriculture, UAS, GKVK, \\ Bengaluru-560065, Karnataka, India \\ ${ }^{2}$ Department of Plant Pathology, UAS, Bengaluru, Karnataka, India \\ ${ }^{3}$ Department of Genetics and Plant Breeding, Institute of Agricultural Sciences, Banaras \\ Hindu University, Varanasi-221005, India \\ *Corresponding author
}

\section{A B S T R A C T}

Bambara groundnut (Vigna subterrenea Verdc. L) is an African pulse crop, cultivated mainly as protein source. The crop is most suitable for arid and semi-arid tropics and

Keywords

YMV, Mutation, Vigna subterrenea Verdc. L,

Heterologous probes

Article Info

Accepted:

23 March 2018

Available Online:

10 April 2018 tolerant to saline soils. Low Productivity of pulses in the country is attributed to many biotic stresses which are ranging from plant ideotype to biotic and abiotic stresses. Among the various diseases, yellow mosaic virus (YMV) disease in pulses and also causes yield losses in Bambara groundnut. Hence the present study was conducted to screen 55 stabilized mutant lines of $\mathrm{M}_{6}$ generation irradiated with gamma irradiation. Five SSR primers were designed using the pick primer tool from the NCBI website for the RGA primer RGA 1F-CG/RGA 1R sequence reported in Vigna mungo due to its sequence similarity found in many of the Vigna species. Hence the same sequence was used to design primers. These heterologous primers were used to screen the isolated and stabilized mutants of Bambara groundnut. However all the designed primers were unable to amplify the mutant lines which infers that either all the lines lack resistance or these markers are not sufficient to identify the linked marker DNA to yellow mosaic virus disease resistance gene in Bambara groundnut. Hence an array of heterologus probes with large number of mutants needs to be screen.

\section{Introduction}

Bambara groundnut is an important food legume crop grown by resource poor farmers mainly in semi-arid parts of African countries. In much of Africa, Bambara groundnut is the third most important legume after groundnut (Arachis hypogaea) and cowpea (Vigna unguiculata) (Howell 1994). Bambara Groundnut [Vigna subterranea (L.) Verdc.] is a member of family Fabaceae and subfamily Faboideae with a chromosome number $2 n=22$. It is an autogamous diploid grain legume $(2 n=22)$. It is cultivated principally by farmers as a "famine culture" crop because it has several natural agronomic advantages including high nutritional value, drought tolerance and the ability to produce in soils considered insufficiently fertile for cultivation of other more favoured species such as 
common beans and groundnuts (Azam-Ali et al., 2001). It is native grain legume of the South Sahara. The common name actually appears to be derived from a tribe "Bambara" who now live mainly in Mali. Bambara groundnut is an herbaceous, intermediate, annual legume, and self-pollinated with a compact well developed tap root with many short lateral stems on which leaves are borne. Leaves are trifoliate and flowers borne in a receme (Basu et al., 2007 and Massawe et al., 2002). Its podding habit is either in the soil or on the surface of the ground (Amadou et al., 2001). It can be cultivated up to $1600 \mathrm{~m}$ above sea level with an average day temperature of $20-28^{\circ} \mathrm{C}$ ideal for the crop, it has a growth period of 110-150 days for the crop to develop, Bambara groundnut will grow on any well drained soil but light sandy or loam.It fixes atmospheric nitrogen in symbiosis with Bradyrhizobium strains through a nodulation process (Gueye et al., 1998). The yield potentials of Bambara groundnut is restricted, because of autogamous nature of the crop, it is difficult to undertake hybridisation, with several attempts at artificial hybridisation reported as unsuccessful (Suwanprasert et al., 2006) and limits genetic variability for quantitative characters. Hence the genetic improvement of the crop was attempted through mutation breeding. Mutation breeding has been considered as much promising shortcut method of breeding which could be useful for the development of the desired varieties of different crop plants. Induced mutations are necessary to enhance rate of genetic variability since spontaneous mutation rate is very slow and that prevents breeders to exploit them in plant breeding programs. Bambara groundnut natural germplasm do not carry any gene for earliness, double seeded pods and yellow mosaic virus disease resistance. In order to fulfil our desired plant ideotype, mutation breeding is considered to play important role in creating genetic diversity with short duration of time. Adu-dapaah et al., (2003) have reported improvement of Bambara groundnut productivity through induced mutation using EMS and gamma radiation and developed resistance to Cercospora, Anthracnose and viruses.

The incidence of yellow mosaic virus disease is a major constraint in cultivation of Vigna spp in all the parts of India and it causes significant losses to the Indian economy every year and Bamabara groundnut being a pulse crop is often susceptible to yellow mosaic virus disease. YMV in Bamabara groundnut was first reported by Muniyappa and Veeresh in (1984) from the field of Agriculture farm, University of Agriculture Sciences, Bangalore and confirmed its transmittance principally by whitefly, Bemisia tabaci with characteristics of faint yellow discolouration of younger and bright yellow colouration older leaves. Smita (2012) also reported similar findings. Her studies has brought with various susceptible and resistant mutant lines for the yellow mosaic virus disease transmitted through whitefly Bemisia tabaci in the gamma irradiated mutant population under natural condition. In recent years, DNA markers are extensively used for tagging of disease resistant genes in markerassisted plant breeding. Indirect selection using DNA markers linked to resistant genes could be one of the alternate approaches as they enable marker assisted selection (MAS) to overcome the inaccuracies in the field evaluation (Selvi et al., 2006). The use of molecular markers for resistance genes is particularly powerful as it removes the delays in breeding programmes associated with the phenotypic analysis (Karthikeyan et al., 2012). This is possible due to availability of many kinds of markers viz. RAPD, AFLP and SSR that are used for genotyping purposes. Realizing the importance and need for such a comprehensive study in Bambara groundnut, the present investigation was undertaken to isolate the YMV disease resistant lines using SSR markers. 


\section{Materials and Methods}

\section{Experimental materials}

The present experiment involved seeds of 55 stabilized $\mathrm{M}_{6}$ mutant lines of variety 'SB-42' treated with the $\mathrm{LD}_{50}(200 \mathrm{~Gy})$ of gamma rays and developed by Vijaykumar 2011 and Smita 2012.

\section{Method}

Seeds of 55 mutant lines were sown in plant to row progeny row in a single replication along with control (SB-42) with spacing of $30 \mathrm{x}$ 10at K-block, GKVK, Bengaluru. Fertilizers dose of 25:75:38 kg per hectare was applied and the field was irrigated once in a week. Suitable crop protection measures were taken during the period of the crop growth.

\section{DNA extraction and quantification}

The genomic DNA was isolated using leaf sample of thirty days old seedlings. DNA was isolated as per the modified Cetyltrimethyl ammonium bromide (CTAB) method (Dellaporta et al., 1983). DNA purity and quantity was determined using Nano Drop ${ }^{\mathrm{TM}}$ spectrophotometer. The ratios between the reading at $260 \mathrm{~nm}$ and $280 \mathrm{~nm}$ provide an estimate of DNA purity. Pure DNA samples will have a ratio of 1.8 . One $\mu \mathrm{L}$ of DNA isolated from Bambara groundnut leaves were fed to the sample pedestal and the absorbance at 260 and $280 \mathrm{~nm}$ were recorded against a buffer blank. A 260/280 nm ratio for all the samples was calculated to check the purity. DNA was quantified using the formula and further all the samples were diluted to a final concentration of $10-20 \mathrm{ng} / \mu \mathrm{L}$.

$\mu \mathrm{g}$ ds $\mathrm{DNA} / \mu \mathrm{L}=(\mathrm{A} 260 * 40) / 2$

For qualitative analysis of DNA agarose gel electrophoresis was used to separate the DNA based on size. Genomic DNA was electrophoresed in $0.8 \%$ agarose.

\section{Designing of primer}

The Vigna mungo resistance protein (VMYR1) gene of the GenBank accession: AY297425.2, which is 445 bp linear DNA reported to be Yellow mosaic virus resistance linked DNA marker sequence in Vigna mungo (Basak et al., 2004) sequence was collected from NCBI (National Centre for Biotechnology Information) site was considered to develop marker as its prevalence was identified by Basic Local Alignment Search Tool (BLAST) in other related species, after this sequence was found to be present in other species of Vigna and is responsible for yellow mosaic virus disease resistance. Hence this gene sequence was considered as a template sequence to design the forward and reverse primers for PCR amplification and genome specific primers were designed using primer-Blast, synthesized from Chromous Biotech, Bangalore, India.

Complete sequence of Vigna mungo resistance protein (VMYR-1)

AGTTTATAATTCGATTGCTGATGATTTT GATAGTTCATGTTTTCTTCAAAATGTAA GAGAAGAATCAAATAAACATGGGTTA AAACACCTCCAGAGCCTCCTTCTTTCA GAAATACTTGGAGAGAACGACATCATC TTAGCAAGTGTGCAAAGAGGAATTTCA GTGATACAACAAAGGCTTGGTAGAAAG AAAGTTCTCTTGATTCTAGATGATGTTG ACAACAGAAAGCAGTTACAAGCATTTG CTGGAAGATCTGATTGGTTTGGTCCCG GCAGCAGAGTTATCGTTACCACTCGGG ACGAACAGCTGCTAAAATCTCATGAGA TTGAAAGAACTTATGAGGTGGAGGAAT TGAATGATAATGATTCTCTTCAATTGCT TATATGGAATGCTTTCAAAAGGGAAAA AGTTGATCCAAGATACGAGGACGTCTT GAATCGTAGT 
Table.1 List of $\mathrm{M}_{6}$ mutant lines of Bambara groundnut selected for molecular screening for yellow mosaic virus disease resistance

\begin{tabular}{|c|c|c|c|c|c|}
\hline $\begin{array}{l}\text { SI. } \\
\text { no }\end{array}$ & Mutants & $\begin{array}{l}\text { SI. } \\
\text { no }\end{array}$ & Mutants & Sl. no & Mutants \\
\hline 1 & $\mathrm{M}_{6} \mathrm{~F}_{1} \mathrm{P}_{7}$ & 19 & $\mathrm{M}_{6} \mathrm{~F}_{21} \mathrm{P}_{2}$ & 38 & $\mathrm{M}_{6} \mathrm{~F}_{41} \mathrm{P}_{6}$ \\
\hline 2 & $\mathrm{M}_{6} \mathrm{~F}_{2} \mathrm{P}_{7}$ & 20 & $\mathrm{M}_{6} \mathrm{~F}_{21} \mathrm{P}_{3}$ & 39 & $\mathrm{M}_{6} \mathrm{~F}_{42} \mathrm{P}_{2}$ \\
\hline 3 & $\mathrm{M}_{6} \mathrm{~F}_{3} \mathrm{P}_{3}$ & 21 & $\mathrm{M}_{6} \mathrm{~F}_{22} \mathrm{P}_{2}$ & 40 & $\mathrm{M}_{6} \mathrm{~F}_{43} \mathrm{P}_{4}$ \\
\hline 4 & $\mathrm{M}_{6} \mathrm{~F}_{4} \mathrm{P}_{6}$ & 22 & $\mathrm{M}_{6} \mathrm{~F}_{23} \mathrm{P}_{1}$ & 41 & $\mathrm{M}_{6} \mathrm{~F}_{42} \mathrm{P}_{2}$ \\
\hline 5 & $\mathrm{M}_{6} \mathrm{~F}_{5} \mathrm{P}_{3}$ & 23 & $\mathrm{M}_{6} \mathrm{~F}_{23} \mathrm{P}_{10}$ & 42 & $\mathrm{M}_{6} \mathrm{~F}_{44} \mathrm{P}_{5}$ \\
\hline 6 & $\mathrm{M}_{6} \mathrm{~F}_{5} \mathrm{P}_{4}$ & 24 & $\mathrm{M}_{6} \mathrm{~F}_{24} \mathrm{P}_{3}$ & 43 & $\mathrm{M}_{6} \mathrm{~F}_{44} \mathrm{P}_{8}$ \\
\hline 7 & $\mathrm{M}_{6} \mathrm{~F}_{7} \mathrm{P}_{1}$ & 25 & $\mathrm{M}_{6} \mathrm{~F}_{25} \mathrm{P}_{2}$ & 44 & $\mathrm{M}_{6} \mathrm{~F}_{45} \mathrm{P}_{4}$ \\
\hline 8 & $\mathrm{M}_{6} \mathrm{~F}_{8} \mathrm{P}_{2}$ & 26 & $\mathrm{M}_{6} \mathrm{~F}_{26} \mathrm{P}_{4}$ & 45 & $\mathrm{M}_{6} \mathrm{~F}_{46} \mathrm{P}_{3}$ \\
\hline 9 & $\mathrm{M}_{6} \mathrm{~F}_{9} \mathrm{P}_{5}$ & 27 & $\mathrm{M}_{6} \mathrm{~F}_{27} \mathrm{P}_{4}$ & 46 & $\mathrm{M}_{6} \mathrm{~F}_{48} \mathrm{P}_{1}$ \\
\hline 10 & $\mathrm{M}_{6} \mathrm{~F}_{11} \mathrm{P}_{5}$ & 28 & $\mathrm{M}_{6} \mathrm{~F}_{29} \mathrm{P}_{2}$ & 47 & $\mathrm{M}_{6} \mathrm{~F}_{49} \mathrm{P}_{2}$ \\
\hline 11 & $\mathrm{M}_{6} \mathrm{~F}_{12} \mathrm{P}_{5}$ & 29 & $\mathrm{M}_{6} \mathrm{~F}_{30} \mathrm{P}_{3}$ & 48 & $\mathrm{M}_{6} \mathrm{~F}_{53} \mathrm{P}_{1}$ \\
\hline 12 & $\mathrm{M}_{6} \mathrm{~F}_{13} \mathrm{P}_{3}$ & 30 & $\mathrm{M}_{6} \mathrm{~F}_{31} \mathrm{P}_{3}$ & 49 & $\mathrm{M}_{6} \mathrm{~F}_{50} \mathrm{P}_{1}$ \\
\hline 13 & $\mathrm{M}_{6} \mathrm{~F}_{14} \mathrm{P}_{5}$ & 31 & $\mathrm{M}_{6} \mathrm{~F}_{32} \mathrm{P}_{1}$ & 50 & $\mathrm{M}_{6} \mathrm{~F}_{50} \mathrm{P}_{5}$ \\
\hline 14 & $\mathrm{M}_{6} \mathrm{~F}_{16} \mathrm{P}_{1}$ & 32 & $\mathrm{M}_{6} \mathrm{~F}_{34} \mathrm{P}_{5}$ & 51 & $\mathrm{M}_{6} \mathrm{~F}_{51} \mathrm{P}_{2}$ \\
\hline 15 & $\mathrm{M}_{6} \mathrm{~F}_{17} \mathrm{P}_{2}$ & 34 & $\mathrm{M}_{6} \mathrm{~F}_{35} \mathrm{P}_{2}$ & 52 & $\mathrm{M}_{6} \mathrm{~F}_{57} \mathrm{P}_{5}$ \\
\hline 16 & $\mathrm{M}_{6} \mathrm{~F}_{18} \mathrm{P}_{6}$ & 35 & $\mathrm{M}_{6} \mathrm{~F}_{37} \mathrm{P}_{3}$ & 53 & $\mathrm{M}_{6} \mathrm{~F}_{58} \mathrm{P}_{4}$ \\
\hline 17 & $\mathrm{M}_{6} \mathrm{~F}_{19} \mathrm{P}_{1}$ & 36 & $\mathrm{M}_{6} \mathrm{~F}_{39} \mathrm{P}_{1}$ & 54 & $\mathrm{M}_{6} \mathrm{~F}_{60} \mathrm{P}_{4}$ \\
\hline 18 & $\mathrm{M}_{6} \mathrm{~F}_{20} \mathrm{P}_{9}$ & 37 & $\mathrm{M}_{6} \mathrm{~F}_{41} \mathrm{P}_{2}$ & 55 & $\mathrm{M}_{6} \mathrm{~F}_{61} \mathrm{P}_{2}$ \\
\hline
\end{tabular}

Table.2 BLAST result for yellow mosaic virus sequence across the Vigna species

\begin{tabular}{|l|l|l|l|l|}
\hline Description & $\begin{array}{l}\text { Total } \\
\text { Score }\end{array}$ & $\begin{array}{l}\text { Query } \\
\text { cover }\end{array}$ & $\begin{array}{l}\text { Max } \\
\text { identity }\end{array}$ & Accession \\
\hline $\begin{array}{l}\text { Vignamungo disease resistance } \\
\text { protein (VMYR-1) gene, partial cds }\end{array}$ & 822 & $100 \%$ & $100 \%$ & AY297425.2 \\
\hline $\begin{array}{l}\text { Vigna radiate viral resistance } \\
\text { candidate (MYR-1) gene, partial cds }\end{array}$ & 673 & $87 \%$ & $98 \%$ & AY301990.1 \\
\hline $\begin{array}{l}\text { Vignamungo disease resistance } \\
\text { protein (MYR-3) mRNA, partial cds }\end{array}$ & 667 & $100 \%$ & $96 \%$ & EF446378.1 \\
\hline $\begin{array}{l}\text { Vignamungo disease resistance } \\
\text { protein (VMYR-2) gene, partial cds }\end{array}$ & 560 & $88 \%$ & $92 \%$ & AY301991.1 \\
\hline $\begin{array}{l}\text { Vignaungiculata clone KIND12 } \\
\text { disease resistance protein homolog } \\
\text { gene, partial cds }\end{array}$ & 307 & $62 \%$ & $87 \%$ & AF141012.1 \\
\hline $\begin{array}{l}\text { Vignaungiculata clone KINE12 } \\
\text { disease resistance protein homolog } \\
\text { gene, partial cds }\end{array}$ & 303 & $62 \%$ & $86 \%$ & AF141013.1 \\
\hline $\begin{array}{l}\text { Vignavexillata disease resistance } \\
\text { protein homolog gene sequence }\end{array}$ & 198 & $63 \%$ & $79 \%$ & AF141014.1 \\
\hline
\end{tabular}


Table.3 Primer sequences obtained for yellow mosaic virus resistant sequence

\begin{tabular}{|c|c|c|c|c|c|c|c|}
\hline sl. no & Sequences & length & start & stop & $\begin{array}{l}\mathrm{Tm} \\
\left({ }^{\circ} \mathrm{C}\right)\end{array}$ & $\begin{array}{l}\mathbf{G}+\mathbf{C} \\
(\%)\end{array}$ & $\begin{array}{l}\text { Product } \\
\text { length }\end{array}$ \\
\hline 1. & $\begin{array}{l}\text { Forward: } \\
\text { ATGATAACTCTGCTGCCGGG } \\
\text { Reverse: } \\
\text { ACCTCCAGACCGTCCTTCTT }\end{array}$ & $\begin{array}{l}20 \\
20\end{array}$ & $\begin{array}{l}101 \\
302\end{array}$ & $\begin{array}{l}120 \\
283\end{array}$ & $\begin{array}{l}59.89 \\
60.18\end{array}$ & $\begin{array}{l}55 \\
55\end{array}$ & 202 \\
\hline 2. & $\begin{array}{l}\text { Forward: } \\
\text { GATAACTCTGCTGCCGGGAC } \\
\text { Reverse: } \\
\text { AACACCTCCAGACCGTCCTT }\end{array}$ & $\begin{array}{l}20 \\
20\end{array}$ & $\begin{array}{l}103 \\
305\end{array}$ & $\begin{array}{l}122 \\
286\end{array}$ & $\begin{array}{l}60.53 \\
60.76\end{array}$ & $\begin{array}{l}60 \\
55\end{array}$ & 203 \\
\hline 3. & $\begin{array}{l}\text { Forward: } \\
\text { ACCTCCAGAGCCTCCTTCTT } \\
\text { Reverse: } \\
\text { CCGGGACCAAACCAATCAA }\end{array}$ & $\begin{array}{l}20 \\
20\end{array}$ & $\begin{array}{l}116 \\
302\end{array}$ & $\begin{array}{l}135 \\
282\end{array}$ & $\begin{array}{l}59.96 \\
59.96\end{array}$ & $\begin{array}{l}55 \\
55\end{array}$ & 192 \\
\hline 4. & $\begin{array}{l}\text { Forward: } \\
\text { CTGTTCGTCCCGAGTGGTAA } \\
\text { Reverse: } \\
\text { AAACACCTCCAGACCGTCCT }\end{array}$ & $\begin{array}{l}20 \\
20\end{array}$ & $\begin{array}{l}82 \\
306\end{array}$ & $\begin{array}{l}101 \\
287\end{array}$ & $\begin{array}{l}59.40 \\
60.76\end{array}$ & $\begin{array}{l}55 \\
55\end{array}$ & 225 \\
\hline 5. & $\begin{array}{l}\text { Forward: } \\
\text { TTTAGCAGCTGTTCGTCCCG } \\
\text { Reverse: } \\
\text { CACCTCCAGACCGTCCTTCT }\end{array}$ & $\begin{array}{l}20 \\
20\end{array}$ & 74 & $\begin{array}{l}93 \\
284\end{array}$ & $\begin{array}{l}60.67 \\
60.90\end{array}$ & 55 & 230 \\
\hline
\end{tabular}

\section{SSR Reaction mixture}

\begin{tabular}{|l|l|}
\hline SSR reaction mixture & $\mathbf{1 x}$ \\
\hline Template DNA (10 ng) & $2.0 \mu \mathrm{l}$ \\
Primer mix (forward and reverse) & $1.0 \mu \mathrm{l}$ \\
dNTP mix (1mM) & $1.0 \mu \mathrm{l}$ \\
Taq buffer (10X) & $1.0 \mu \mathrm{l}$ \\
Taq polymerase (5U/ul) & $0.3 \mu \mathrm{l}$ \\
Sterile water & $4.7 \mu \mathrm{l}$ \\
\hline Total & $\mathbf{1 0 . 0} \boldsymbol{\mu l}$
\end{tabular}

Amplification condition

\begin{tabular}{|l|l|l|l|}
\hline Steps & Reactions & Temp $\left({ }^{0}\right.$ C) & Duration \\
\hline 1: & Initial denaturation & 94 & $4 \mathrm{~min}$ \\
\hline 2: & Denaturation & 94 & $1 \mathrm{~min}$ \\
\hline $3:$ & Annealing & 60 & $45 \mathrm{sec}$ \\
\hline $4:$ & Extension & 72 & $1 \mathrm{~min}$ \\
\hline $5:$ & Final Extension & 72 & $8 \mathrm{~min}$ \\
\hline 6 : & Hold & 4 & $30 \mathrm{~min}$ \\
\hline
\end{tabular}


Plate.1 Yellow mosaic virus disease susceptible plant

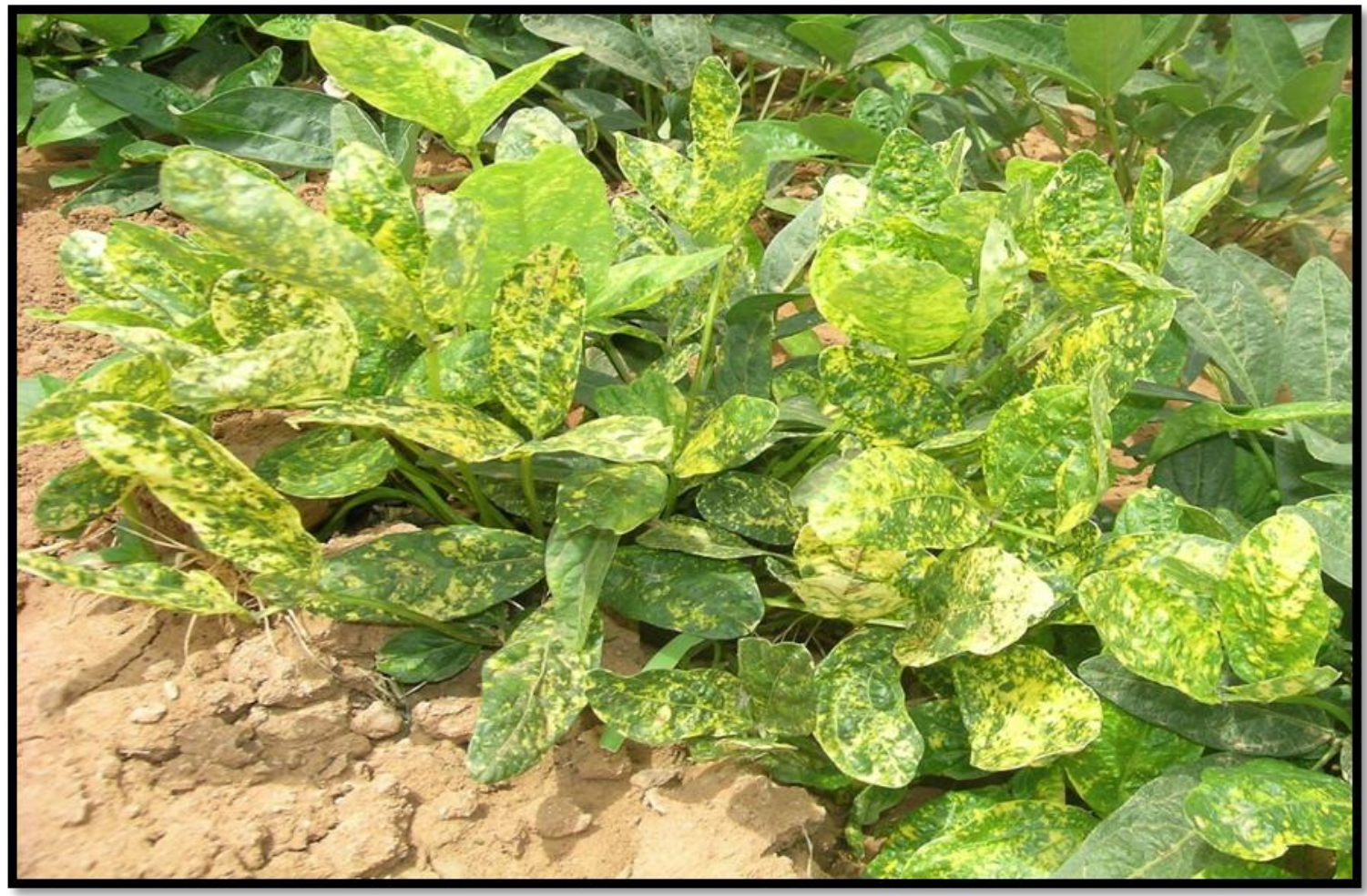

Plate.2 Yellow mosaic virus disease resistant plant

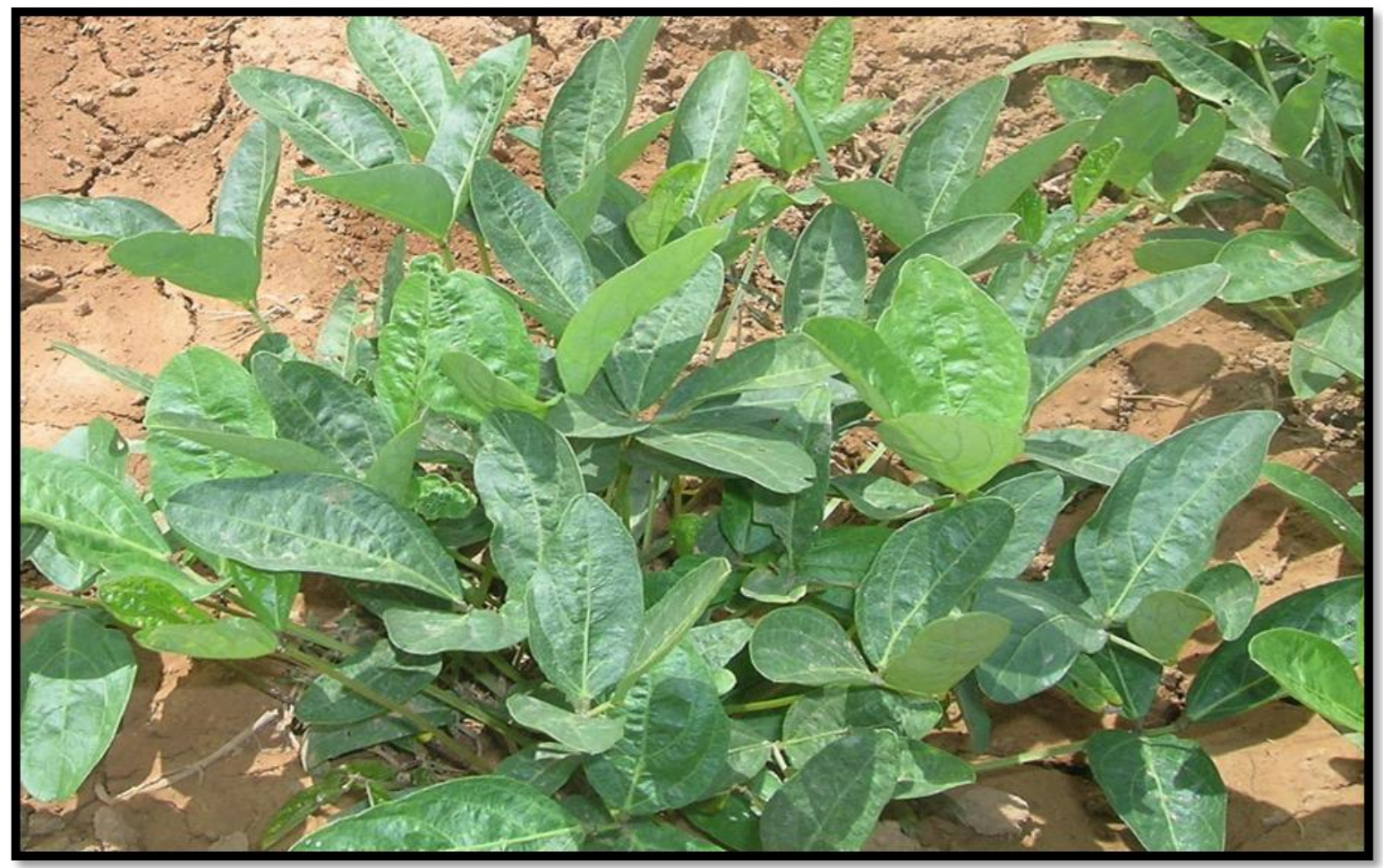




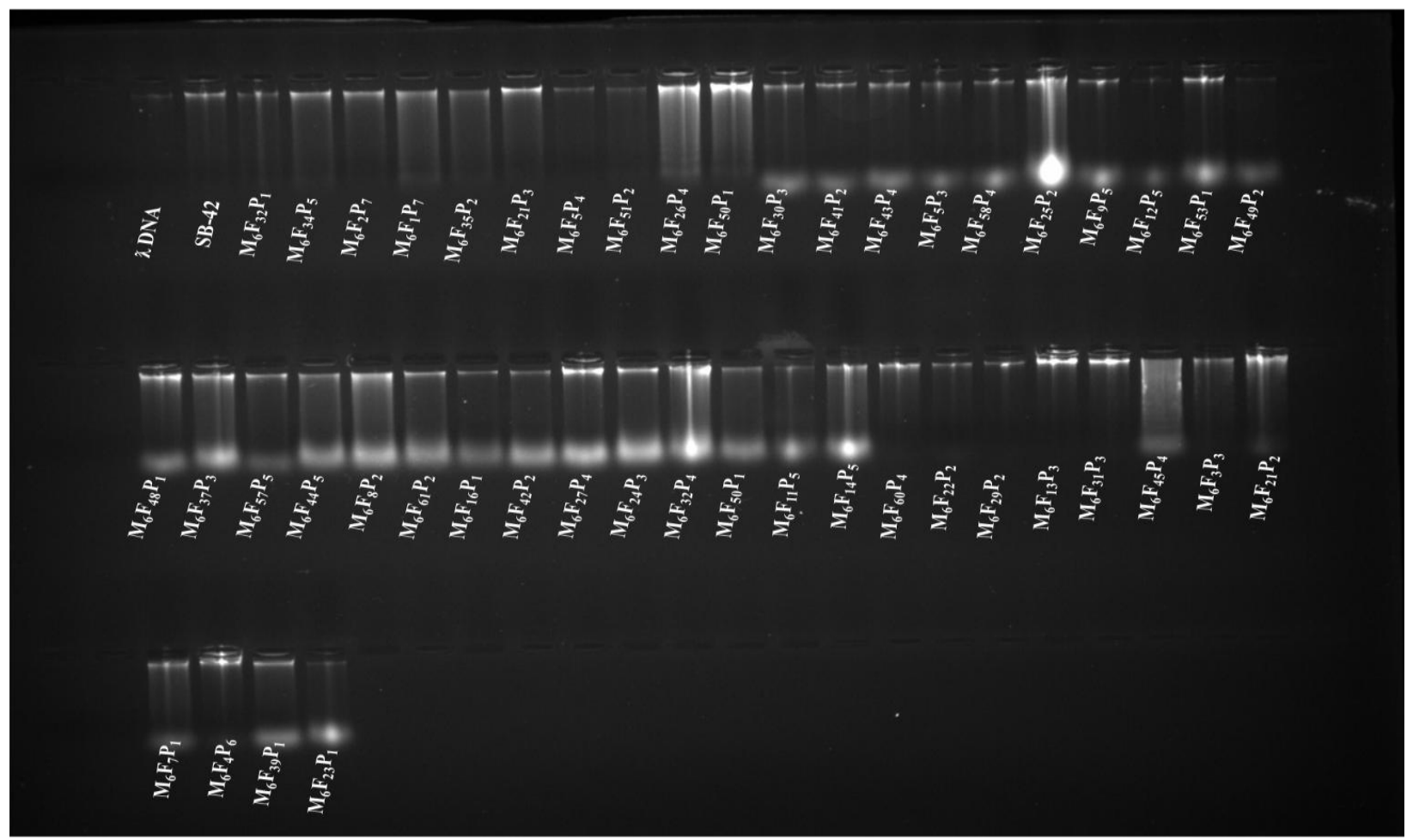

\section{SSR Reaction mixture}

The SSR reaction mixture consisted of $2 \mu \mathrm{L}$ of template DNA, $0.5 \mu \mathrm{L}$ of each of forward and reverse primer, $2 \mathrm{X}$ PCR master mix containing Taq DNA polymerase, assay buffer and dNTPs in a volume of $10 \mu$ l. The PCR mixture for one reaction is given below.

\section{Amplification condition}

Eppendorf PCR programme me was used to amplify the DNA fragments. The primers used in the study were with the different annealing temperature. The details of the programme used are given below.

\section{Gel electrophoresis}

The product were analyzed using $2 \%$ agarose gel in a volume of electrophoresis buffer (1x TBE) sufficient for constructing a gel. Ethidium bromide was added at concentration of $0.5 \mu \mathrm{g} / \mathrm{ml}$ of gel. The gel was allowed to set fully before removing the comb and loading the sample. Three $\mu \mathrm{l}$ of loading dye was added to $10 \mu \mathrm{l}$ of PCR products and mixed well before loading into the wells. Care was taken to prevent mixing of samples between the wells. A current of $60 \mathrm{~V}$ for 45min and after the electrophoresis, the DNA banding pattern was viewed under UV transilluminator (BIO-RAD gel documentation system) and documented.

\section{Results and Discussion}

Yellow mosaic virus disease is one of the most devastating disease causing hundred per cent economic loss in most of the Vigna spp. Hence there is need of developing resistant varieties. Bambara groundnut is an autogamous and underutilized crop because of negligence in the improvement of crop however since it is protein rich pulse crop and shown sporadic incidence of YMV disease. In 
this context screening of YMV disease under laboratory condition by using the SSR markers for both susceptible and resistant to YMV. Fifty five mutant lines of Bambara groundnut (Vigna subterranea) were sown during kharif 2014 under natural condition at gkvk campus, UAS Bengaluru. These mutant lines were shown resistance and susceptible for yellow mosaic virus under natural condition as reported by Smita (2012). DNA was extracted using modified method of Dellaporta et al., (1983) and agarose gel electrophoresis results showed band intensities of DNA isolated from the 55 mutant lines were stable and of good quality and suitable for molecular studies. These mutants were screened for YMV disease under the laboratory using the developed five simple sequence repeat (SSR) markers (Table 1-3). However on electroporosis none of the five primers showed amplification for DNA marker linked to the yellow mosaic virus disease resistance. However all the primers were unable to amplify these mutant lines which infers that these markers are either not sufficient to identify the linked marker DNA to yellow mosaic virus disease resistance gene in Bambara groundnut or it is possible that all the genotypes screened were susceptible. Hence an array of heterologous probes with large number of mutants needs to be screened.

\section{References}

Adu-dapaah, H. K., Asibuo, J. Y., Danquah, O. A., Owusuakyaw, M. and Haleegoah, J., 2003, Bambara groundnut improvement through mutation breeding in Ghana, In: Proceedings of a final Research Coordination Meeting organized by the Joint FAO/IAEA Division of Nuclear Techniques in Food and Agriculture and held in Pretoria, South Africa, p. 19-23.

Amadou, H. I., Bebeli, P. J. and Kaltsikes, P. J., 2001, Genetic diversity in Bambara groundnut (Vigna subterranea L.) germplasm revealed by RAPD makers.Genome.44: 995-999.

Azam-Ali, S. N., Sesay, A., Karikari, K. S., Massawe, F. J., Aguilar-Manjarrez, J., Bannayan, M. and Hampson, K. J., 2001, Assessing the potential of an underutilized crop - a case study using bambara groundnut. Exp. Agric., 37: 433-472.

Basak, J., Kundagrami, S., Ghose, T. K. and Pal, A., 2004, Development of Yellow Mosaic Virus (YMV) resistance linked DNA marker in Vigna mungo from populations segregating for YMVreaction. Molecular Breeding, 14: 375383.

Basu, S. N., Roberts, J. A., Azam-Ali, and Mayes, S., 2007, Bambara groundnut.Genome Mapping and Mol. Breed. Plants, 3: 157-173.

Dellaporta, S. L. Wood, J. and Hicks, J. B. 1983. A plant DNA mini preparation: Version II. Plant Molecular Biology Reporter, 1: 19-21.

Gueye, M., James, E. K., Kierans, M. and Sprent, J. L., 1998, The development and structure of root nodules on Bambara groundnut [Voandzeia (Vigna) subterranea]. World J. Microbio. Biotech., 14: 177-184.

Howell, J. A., 1994, Common names given to Bambara groundnut (Vigna subterranea: Fabaceae) in central Madgascar. Econ. Bot. p 48: 217-222.

Karthikeyan, A., Sudha, M., Senthil, N., Pandiyan, M., Raveendran, M. and Nagarajan, P., 2012, Screening and identification of RAPD markers linked to MYMV resistance in mungbean (Vigna radiate L Wilczek). Arch. Phytopatho. Plant Prot. 45(6): 712716.

Massawe, F. J., Dickinson, M., Roberts, J. A. and Azam-Ali, S. N., 2002, Genetic diversity in Bambara groundnut (Vigna 
subterranean L. Verdc).Genome.45: $1175-1180$.

Muniyappa, V. and Veeresh, G. K., 1984, Plant virus disease transmitted by whiteflies in Karnataka. Proc. Indian Acad. Sci. (Anim. Sci.), 9(4): 397-406.

Selvi, R., Muthiah, A. R., Manivannan, N. and Manickam, A., 2006, Tagging of RAPD marker for MYMV resistance in mungbean (Vigna radiata L. Wilczek). Asian J. Plant Sci., 5: 277-280.

Smita, S. V., 2012, Studies on genetic variability in $\mathrm{M}_{3}$ generation of Bambara groundnut (Vigna subterranean L. Verdc.) treated with gamma rays. M.Sc. Thesis, Univ. Agric. Sci., Bengaluru.

Suwanprasert, J., Toojinda, T., Srinives, P. and Chanprame, S., 2006, Hybridization technique of Bambara groundnut (Vigna subterranea), Breeding Sci., 56: 125 129.

Vijaykumar, L., 2011, Gamma irradiated variability studies in Bambara groundnut (Vigna subterranea L. Verdc). M.Sc Thesis, Univ. Agric. Sci., Bengaluru.

\section{How to cite this article:}

Pranesh, R. Nandini, Kailash Chandra and Nagaraju, N. 2018. Screening of Bambara Groundnut (Vigna subterrenea Verdc. L.) Mutant Lines for Yellow Mosaic Virus Disease Resistance Using SSR Markers. Int.J.Curr.Microbiol.App.Sci. 7(04): 2872-2880. doi: https://doi.org/10.20546/ijcmas.2018.704.327 